\title{
The Investigation of the Book "The Education of Little Tree" within Context of Instructional Principles
}

\author{
Fulya Zorlu*, Cevat Eker \\ Curriculum and Instruction Department, Faculty of Education, Bulent Ecevit University, Republic of Turkey
}

Copyright $(2016$ by authors, all rights reserved. Authors agree that this article remains permanently open access under the terms of the Creative Commons Attribution License 4.0 International License

\begin{abstract}
It is aimed to investigate "The Education of Little Tree" (a novel book) in relation with instructional principles. By taking into consideration the principles; "Student Relativity", "Connection to Life", "From the Near to the Far", "From the Known to the Unknown", "Clarity", "From the Concrete to the Abstract", "Economy", "Learning by Doing and Experiencing", and "Integrity" wholeness, the checklist was prepared and the convenience of the chosen book was analyzed. In this study, of the qualitative research methods, document review method was used. Content analysis method, one of the qualitative methods, was used within the study. Results show that instructional principles are taken into account in the novel book and it is in accordance with the instructional principles, especially the ones; "Student Relativity", "Connection to Life", "Clarity", "From the Concrete to the Abstract", "From the Known to the Unknown" and "Learning by Doing and Experiencing". Furthermore, it is remarkable that the information given to the boy was taken in a concrete way.
\end{abstract}

Keywords Teaching, The Education of Little Tree, Instructional Principles

\section{Introduction}

Some orientations occurring in social and educational issues make changing and innovation obligatory in education of the children. While education of the children was provided by parents with regulations within the family and based on learning the life style in the beginning, it is attempted to be realized by assigning the people who can communicate with children and young people more easily and effectively as educators within the society later on. However, education is not an activity performed only in the school and by the teachers; it is experienced in anywhere as a versatile process covering the whole life and activities of a person. Thus, a lot of definitions of education can be made. Evaluating the definitions that have been made so far in a common framework, education is development, upbringing, socialization, acculturation, adaptation process to society, enlightenment, and behavioral change and development [1].

Teaching covers a special area of education. Teaching is the processes performed in planned, programmed and supported way for a certain student group and certain content [2-3]. Realization of the goals determined in education and teaching depends on the effectivity of teaching and learning processes in the education and teaching activities [4]. The teachers who think that the process is not realized in the desired level and their teaching is not understood will change their approach, on the contrary; it the students understand the material presented to them, the teachers tend to continue with their current approaches [5]. In this process teaching principles should be obeyed in order to reach the goals determined [6]. Teaching processes appear in some areas such as developing the teaching programs, preparing the books to be used in the application of the programs, selecting the tools and materials, teaching the lessons by the teachers in the class. Main teaching principles can be defined as student relativity, connection to life, from the near to the far, from the known to the unknown, clarity, from the concrete to the abstract, economy, learning by doing and experiencing, and integrity [7]. Student relativity principle is related to the fact that mental and physical development characteristics, interests and needs of the student play an important role in his/her learning while the subjects to be taught are determined along with considering the individual differences, physiological and psychological characteristics of the student in the teaching regulation process [8]. In this principle, it is emphasized that teaching can be performed by knowing the learner well. Interest, need and characteristics of the learner are essential [9]. From the near to the far principle is explained with the requirement of taking the nearest environment of the learner as a basis both naturally and socially in the regulation of the information to be taught and in giving the examples [10]. From the known to the unknown principle is to be based on the information and experiences of the learner up to that time and adding the new information and experiences on them [8]. A more 
meaningful learning is realized with the comparison of the new information and old information [8]. Clarity principle emphasizes that everything should be open, clear and understandable in the teaching process and should address several sense organs of the learner [11]. According to from the concrete to the abstract principle, a person always learns the thing s/he sees and perceives concretely more easily than the description of the same with abstract concepts. First of all, concrete expressions should be taught and then $\mathrm{s} / \mathrm{he}$ is enabled to understand the abstract expressions in time [10-11]. Economy principle means the regulation of any type of education-teaching activity by spending the shortest time, minimum effort and energy in a way to obtain maximum efficiency [10]. Connection to life principle explains that valuable, auxiliary, usable educational contents of the student for his/her today's and future life, school and lessons are required to be the life itself, and natural and pure educational forms brought by the student from within his/her life are required to be taken as a lesson [12]. Integrity principle explains that the learner is required to be considered as an integrity in terms of physical and psychological powers (e.g. thought, emotion, will) and all his/her aspects should be educated in a balanced way [13]. Learning by doing and experiencing principle relates to the learning environments in which the learner is active both physically and mentally [14].

Teaching principles are an important guide for the educators to reach the goals determined. It is quite important to consider these principles in the learning environments. Thus, teaching principles should be known and adopted. Stories and novels, as in many subjects, have a role in the understanding of the teaching principles. Looking at the literature, generally the teaching principles provided in the course books are observed to be searched [14-15-16-17]. However, it is seen that examination of the novels or story books with the purpose of education, which are accepted in the world, in terms of the teaching principles has not been made. Examination of such books is quite important for indicating the parts to be given as example for the teaching principles and making the said parts more understandable. In this direction, the aim of this study is to examine the book called "The Education of Little Tree" in terms of its compatibility with the teaching principles. The document selected in this context is attempted to be evaluated by the researcher by considering nine teaching principles.

\section{Materials and Methods}

\subsection{Research Design}

In this study, of the qualitative research methods, document review method was used. Qualitative researches are the researches in which qualitative data collection methods such as observation, interview and document [18] analysis are used and a qualitative process for revealing the perceptions and events in a natural environment in a realistic and integrated way is followed. Descriptive analysis is for examining the data according to the predetermined themes [19].

\subsection{Instrumentation}

The author of the novel book "The Education of Little Tree" used as a research material is Forrest Carter. The real name of the author is Asa Earl Carter. This novel book of Forrest Carter was published in 1976. Adaptation of the book into Turkish was made by Şen Süer Kaya. The basic purpose of "The Education of Little Tree" is education. The book is composed of 21 chapters. In the first chapter Little Tree is introduced. The book is divided into chapters according to the events in which Little Tree, main character, is educated. Except for the first chapter, the information regarding the education of Little Tree is given in the other 20 chapters. The information about the chapters of the book is given in Table 1.

Table 1. Parts of the book "The Education of Little Tree"

\begin{tabular}{|c|c|c|c|c|c|}
\hline Number & Chapter & Number & Chapter & Number & Chapter \\
\hline 1 & $\begin{array}{l}\text { Little } \\
\text { Tree }\end{array}$ & 8 & $\begin{array}{c}\text { The Secret } \\
\text { Place }\end{array}$ & 15 & $\begin{array}{c}\text { Willow } \\
\text { John }\end{array}$ \\
\hline 2 & $\begin{array}{l}\text { The } \\
\text { Way }\end{array}$ & 9 & $\begin{array}{l}\text { Grandpa's } \\
\text { Trade }\end{array}$ & 16 & $\begin{array}{l}\text { Church- } \\
\text { Going }\end{array}$ \\
\hline 3 & $\begin{array}{c}\text { Shadows } \\
\text { on a } \\
\text { Cabin } \\
\text { Wall }\end{array}$ & 10 & $\begin{array}{l}\text { Trading } \\
\text { with a } \\
\text { Christian }\end{array}$ & 17 & Mr. Wine \\
\hline 4 & $\begin{array}{l}\text { Fox and } \\
\text { Hounds }\end{array}$ & 11 & $\begin{array}{l}\text { At The } \\
\text { Crossroads } \\
\text { Store }\end{array}$ & 18 & $\begin{array}{l}\text { Down } \\
\text { From } \\
\text { The } \\
\text { Mountain }\end{array}$ \\
\hline 5 & $\begin{array}{l}\text { I Kin } \\
\text { Ye, } \\
\text { Bonnie } \\
\text { Bee }\end{array}$ & 12 & $\begin{array}{c}\text { A } \\
\text { Dangerous } \\
\text { Adventure }\end{array}$ & 19 & $\begin{array}{c}\text { The Dog } \\
\text { Star }\end{array}$ \\
\hline 6 & $\begin{array}{c}\text { To } \\
\text { Know } \\
\text { The Past }\end{array}$ & 13 & $\begin{array}{l}\text { The Farm } \\
\text { in the } \\
\text { Clearing }\end{array}$ & 20 & $\begin{array}{l}\text { Home } \\
\text { Again }\end{array}$ \\
\hline 7 & $\begin{array}{l}\text { Pine } \\
\text { Billy }\end{array}$ & 14 & $\begin{array}{l}\text { A Night } \\
\text { On The } \\
\text { Mountain }\end{array}$ & 21 & $\begin{array}{l}\text { The } \\
\text { Passing } \\
\text { Song }\end{array}$ \\
\hline
\end{tabular}

\subsection{Data Collection and Analysis}

The novel book called "The Education of Little Tree" was examined based on nine instructional principles which was the foundation after the review and determined as Student Relativity, Connection to Life, From the Near to the Far, From the Known to the Unknown, Clarity, From the Concrete to the Abstract, Economy, Learning by Doing and Experiencing, and Integrity in the Primary School Teaching Program [7]. These principles were determined in the "Checklist". The checklist has been created than the principles. This checklist was utilized in order to determine to what extent the instructional principles are provided in the document. A title is given for each principle, and it is 
detected to which principle the information and applications provided in the book are suitable by means of the checklist and thus analysis is attempted to be made. This analysis is done separately by two investigators. Then compared and was finalized.

\section{Examination of "Little Tree" Chapter of the Book according to the Teaching Principles}

In this chapter of the book, Little Tree is introduced and it is mentioned that his parents died when he was small and he lives with his grandparents. Moreover, information regarding the grandparents of Little Tree is also given in this chapter. No example is given from education and teaching in this chapter. Therefore, teaching principles are not mentioned in this chapter.

\section{Examination of "The Way" Chapter of the Book according to the Teaching Principles}

In this chapter of the book, the events that Little Tree and his grandpa experienced in a turkey hunting they went are told. It is emphasized that as the hawk catching the quail in the turkey hunting is fast, it caught the slow quail. It is mentioned that of the five turkeys falling into the trap, only three turkeys needed should be taken, that's the way it is. Thus, the importance of having property as much as the needs of people is emphasized. In this chapter, "From the Known to the Unknown" and "Connection to Life" teaching principles are given. Giving the event in which the hawk caught its prey with the information of fast-slow can be explained with "From the Known to the Unknown" principle while taking only the three turkeys from the five turkeys falling into the trap can be explained with "Connection to Life" principle.

\section{Examination of "Shadows on a Cabin Wall" Chapter of the Book according to the Teaching Principles}

In this chapter of the book, how Little Tree is educated while living with his grandparents is mentioned. It is told that grandpa is illiterate, grandma reads book every night and they criticize the characters by commenting on the events in the book together. Besides, it is stated that Little Tree learns five words starting with the letter he should learn each week in order to learn the letters of the alphabet. Moreover it is emphasized that grandpa calls people such as officers, sheriff, politicians "the law" with the thought of not paying attention to how other people live and make a living and he uses these words in the conversations with Little Tree. In this chapter, "Learner Relativity" and "From the Concrete to the Abstract" principles are included. The section intended to be taught for providing the learning of one word each week for the education of Little Tree and providing the easy comprehension of the words and their meanings is divided into parts. "Learner Relativity" principle is attempted to be considered in education. It is seen that concretization method is used in the teaching of the concepts. Teaching an abstract expression (like concepts) to a child in the concrete operational stage is difficult. Instead of this, concretization is more appropriate. Thereby, "From the Concrete to the Abstract" principle is attempted to be considered.

\section{Examination of "Fox and Hounds" Chapter of the Book according to the Teaching Principles}

In this chapter of the book, observations of Little Tree and his grandpa regarding the fox and hound dogs are included, and the reasons for grandpa's having two hound dogs, one being young and the other being older, are discussed. According to grandpa, giving the young dog along with the older dog means honoring the older dog and combining its sense of hearing and smell with the agility of the young dog. In this chapter, the moments in which Little Tree and his grandpa watch cunningness of a fox and the behaviors of the dogs against this are told. In this chapter, "Clarity" and "Activity" teaching principles are included. Little Tree is asked to observe the behaviors of the fox and learn the techniques of fox hunting. It can be given as an example to "Activity" principle. Moreover, in this situation telling why two dogs are used can be given as an example to "Clarity" principle.

\section{Examination of "I Kin Ye, Bonnie Bee" Chapter of the Book according to the Teaching Principles}

In this chapter of the book, meaning of the word 'cognate' for Little Tree is discussed and it is emphasized that the meaning is love and understanding. The happiness Little Tree feel from the love between his grandparents and his learning that the fatal problems of the people result from not having this love and understanding are told. In this chapter, "Learner Relativity", "Clarity", "Connection to Life" and "Activity" teaching principles are included. Teaching the word 'cognate' can be given as an example to "Learner Relativity" and "Clarity" principles. Love and the conditions without love, explaining the fatal problems experienced can be given as an example to "Connection to Life" and "Activity" principles.

\section{Examination of "To Know The Past" Chapter of the Book according to the Teaching Principles}

In this chapter of the book, the things grandparents did are told for Little Tree to know his past. Observations of Little Tree, who visited the graves of his parents several times, regarding that there are traces of their customs and traditions in the graves are stated. In this chapter, "From the Near to the Far", "Socialization" and "Activity" teaching principles are included. Visiting the graves and learning the social values starting from the family can be given as an example to "From the Near to the Far" while learning his past by mentally active thinking by himself can be given as an example to "Activity" principle. Teaching the customs and traditions can be given as an example to "Socialization" principle.

\section{Examination of "Pine Billy" Chapter of the Book according to the Teaching Principles}

In this chapter of the book, training of Little Tree in the 
field is mentioned. It is emphasized that they never work so long and fast that they will be tired of the work in the field, and it is told that while driving the plow, failure in ploughing the field in a desired manner due to the fact that one eye of the mule is blind in fact teaches the person to be patient. Firsthand personality characteristics of Pine Billy, after whom the chapter is named, are exemplified with the behaviors he exhibits against various situations. In this chapter, "Learner Relativity" teaching principle is included. That the characters never work so long and fast that they will be tired of the work in the field, it is made by considering the characteristics of the individual can be given as an example to "Learner Relativity" principle.

\section{Examination of "The Secret Place" Chapter of the Book according to the Teaching Principles}

In this chapter of the book, how Little Tree and his grandpa act against various events and the advices given by the grandpa are mentioned. According to grandpa, when one encounters a god thing, it should be absolutely shared. Moreover, the hidden place owned by Little Tree is mentioned and it is emphasized that the presence of such a hidden place is in fact true. In the chapter in which the thoughts of grandma are also shared, the thought that there are two types of mind of people related to living of the body and living of the soul is transferred and the opinion that the trees also have soul is attempted to be adopted with an event. In this chapter, "Integrity" teaching principle is included. Teaching of grandma that there are physical and spiritual mind can be given as an example to "Integrity" principle.

\section{Examination of "Grandpa's Trade" Chapter of the Book according to the Teaching Principles}

In this chapter of the book, the things done by Little Tree and his grandpa for a living are told. In this chapter in which it is emphasized that everything should be done without guile, various benefits of whisky, which is known as an alcoholic drink, in terms of health are also mentioned. In this chapter, "Clarity" teaching principle is included. Teaching the things required to be done for a living and that everything should be done without guile can be given as an example to "Clarity" principle.

\section{Examination of "Trading with a Christian" Chapter of the Book according to the Teaching Principles}

In this chapter of the book, it is emphasized that it is necessary to be careful in human relations. It is told that faulty actions of Little Tree are deliberately not prevented by his grandpa and it is attempted to provide him to realize his fault by experiencing by himself later. In this chapter, "Socialization" and "Activity" teaching principles are included. Little Tree's correcting his faults by realizing them by himself, namely instead of giving the information directly, learner's learning by doing and experiencing can be given as an example to "Activity" and teaching the information about human relations can be given as an example to "Socialization" principle.

\section{Examination of "At The Crossroads Store" Chapter of the Book according to the Teaching Principles}

In this chapter of the book, the event between Little Tree and a girl he meets while selling whisky is included. It is told that Little Tree continues learning words while selling whisky and learns swearwords from his grandpa. In the chapter, meaning of the concept of pride is discussed and the qualities a proud person is required to have are mentioned. In this chapter, "From the Concrete to the Abstract" teaching principle is included. Teaching the features of the concept of pride can be given as an example to "From the Concrete to the Abstract" principle. Moreover, it is attempted to draw attention to informal education such as learning swearwords. It is because teaching and learning can be provided informally as much as formally and it is also necessary to consider such conditions likely to be encountered in life.

\section{Examination of "A Dangerous Adventure" Chapter of the Book according to the Teaching Principles}

In this chapter of the book, how Little Tree learns what is grown in which season and when fruit and vegetables will be picked is told. During this training of Little Tree in nature, it is attention-grabbing to define the things experienced after the grandpa is bitten by a snake as destiny beyond lack of attention. In this chapter, "Connection to Life" and "Clarity" teaching principles are included. In this chapter of the book, Little Tree's learning what is grown in which season and when fruit and vegetables will be picked can be given as an example to "Connection to Life" and "Clarity" principles.

\section{Examination of "The Farm in the Clearing" Chapter of the Book according to the Teaching Principles}

In this chapter of the book, it is mentioned that territories of grandpa are occupied by United Nations and they are fired from their territories. It is mentioned that the fields in which agriculture was taught by the soldiers in the beginning are occupied by force by the same soldiers later. It is emphasized that the grandpa, in the process of growing products to agriculture, guarantees himself and catches fish so as to not to go hungry and he recommends it to Little Tree.

In this chapter, "Connection to Life" and "Clarity" teaching principles are included. Teaching the reason for fishing can be given as an example to "Connection to Life" and "Clarity" principles.

\section{Examination of "A Night On The Mountain" Chapter of the Book according to the Teaching Principles}

In this chapter of the book, Little Tree and his grandpa's encountering two outsiders in the mountain and the events between them are mentioned.

It is mentioned that the outsiders are in a miserable condition due to not being used to living in the mountain conditions and grandpa saves them and finds food for them. It is told that the money earned from the help of Little Tree while grandpa is doing the things above belongs to Little Tree. Thereby, the thought that the price of the things done 
on behalf of another person should be paid in full amount is emphasized. In this chapter, "Connection to Life" and "Integrity" teaching principles are included. With the thought of paying the price of the things done on behalf of another person in full amount, teaching Little Tree that the Outsiders are in a miserable condition due to not being used to living in the mountain conditions and grandpa saves them and finds food for them can be given as an example to "Connection to Life" and "Integrity" principles.

\section{Examination of "Willow John" Chapter of the Book according to the Teaching Principles}

In this chapter of the book, it is mentioned that Little Tree learns how to understand a good ripe watermelon and Little Tree selects the best watermelon among the watermelons they grow in order to enhance this training. Moreover, it is understood that Little Tree is informed in terms of religious education in the conversations between their acquaintance called Willow John and him in the church. It is indicated that it is attempted to provide Little Tree with the value of helpfulness by explaining that since Willow John is a person living alone, they try to help him. In this chapter, "Activity" and "Socialization" teaching principles are included. Learning the good watermelon can be given as an example to "Activity", providing the value of Helpfulness can be given as an example to "Socialization" principle.

\section{Examination of "Church-Going" Chapter of the Book according to the Teaching Principles}

In this chapter of the book, it is seen that religious education of Little Tree is continued. It is told him that there are a lot of religions, but it is stated that telling the evil deeds he did to a beadle to confess will be a problem and he should not do this. Moreover in the chapter, it is told that grandpa gives the chair he made to a person whose house is burnt as a gift. It is because grandpa, while giving the chair he made to the person as a gift, also taught how he made it. Here it is emphasized that people who always like giving something to a person are arrogant and what is right is also to teach that person how to do the things given as a gift. In this chapter, "Clarity" and "Socialization" teaching principles are included. Also, teaching that person how to do the things given as a gift can be given as an example to "Clarity" and "Socialization" principles.

\section{Examination of "Mr. Wine" Chapter of the Book according to the Teaching Principles}

In this chapter of the book, Mr. Wine character is introduced. Moreover, training of Little Tree is continued in the conversations between Mr. Wine and Little Tree. It is emphasized that one habit leads to another habit and bad habits result in a bad personality. It is told that training is an issue with two parts, the technical part which means how to advance in the work and the valuation part. It is stated that in the event of taking photos between Mr. Wine, grandpa and Little Tree, despite taking the photo of the wrong place, grandpa admires it since it is the photo taken by him, thereby the importance given by the people to the actions they perform is attempted to be given. In this chapter, "Connection to Life" and "Clarity" teaching principles are included. Teaching the reason for why bad habits result in bad personality can be given as an example to "Connection to Life" and "Clarity" principles.

\section{Examination of "Down From The Mountain" Chapter of the Book according to the Teaching Principles}

In this chapter of the book, the necessity to bring Little Tree to the orphanage by the officials since it is thought that Little Tree cannot be educated well by his grandparents and the emotional moments that Little Tree has while he is leaving them are told. Thereby, it is attempted to emphasize that people are not the existence composed only of mind and logic and they also have an aspect of feeling. It is indicated that Little Tree is happy with the education given by his grandparents. In this chapter, "Integrity" teaching principle is included. Teaching that people are not the existence composed only of mind and logic and they also have an aspect of feeling can be given as an example to "Integrity" principle.

\section{Examination of "The Dog Star" Chapter of the Book according to the Teaching Principles}

In this chapter of the book, the events experienced by Little Tree in the orphanage are mentioned. It is seen that Little Tree does not move away from telling the right answer to the questions asked him even if this is not appropriate and it is stated that he does not cry for the punishment given in return, since he learned to endure the pain. Little Tree thinks that he communicates with his grandparents by looking at the Dog Star in the sky, tells them the uneasy conditions he is in and is relaxed in this way. In this chapter, "Activity" teaching principle is included. Learning to endure the pain can be given as an example to "Activity" principle.

\section{Examination of "Home Again" Chapter of the Book according to the Teaching Principles}

In this chapter of the book, the moments in which Little Tree returns to his home from the orphanage are told. The thought that making a person happy upon Little Tree's mentioning his friend in the orphanage and his grandpa's deciding to send a gift to him is in the first place is told. It is indicated that religious education of Little Tree is in a good level as he goes to the church in the first morning when he came home. In this chapter, "Socialization" teaching principle is included. Making a friend, telling about him and being happy when his grandpa sends a gift to him can be given as an example to "Socialization" principle.

\section{Examination of "The Passing Song" Chapter of the Book according to the Teaching Principles}

In this chapter of the book, death of Little Tree's grandparents is mentioned. It is indicated that Little Tree starts to obtain whisky by distillation as much as he learned from his grandpa, but since he did not learn well, he quits this 
work so as to not manufacture bad products. That Little Tree buries the materials used in the production so that nobody can manufacture bad products shows the value for his work. It is indicated that belief in life beyond death is taught to Little Tree since he buries his dog in a high mountain thinking that this will facilitate reaching the dead grandpa after the death of his dog. In this chapter, importance of the education of individual is emphasized. The behaviors to be exhibited when an individual is educated with a right education are mentioned. It is seen that Little Tree chooses not make production instead of a bad production and he takes precautions so that they are not caught by bad intended people. In this chapter it is especially emphasized that the individuals abstain from crime and bad behaviors thanks to being taught the values. Little Tree's learning the belief in life beyond death can be given as an example to informal education.

\section{Conclusions}

Stories and novels are provided to readers different life, occurrences, environments and cultures [20]. So it has helped to have different perspectives such as critical thinking, decision making, gain skills [21-22]. Fiction book (stories and novels) have an important place in the education process that want to acquire these skills of students [23-24].

In the subchapters, in which the education of a small child with Indian culture is told, basic principles of instructional are considered. The fiction book "The Education of Little Tree" carries the massage or seems to suggest that a good education can be provided by considering the instructional principles. "Learner Relativity", "Clarity", "From the Concrete to the Abstract", "From the Known to the Unknown" and "Activity" principles are especially emphasized. But this book is studied "From the Known to the Unknown" and "From the Near to the Far" principles have been found to contain fewer samples according to other principles. Moreover, it is attempted to raise human sensitivity in the reader thanks to the advices given partly in the book. Teaching of the values constituting the culture of a society is also emphasized by drawing attention to the values such as religious education.

It is seen that regarding that the content addresses the developmental characteristics of the child and cognitive structure is paid attention. Reference is also made to the effectivity of the methods such as experiment and performance provided in the schools in which the students are active in the process by allowing the learner to explain his/her personal opinions, develop his/her skills in a free environment. Especially, the importance of dealing with the concepts concretely for providing the concepts in early ages is discussed [25-26].

The content suitable to the nature of the child is presented in the book called "The Education of Little Tree". It is emphasized that making observation is much more different than looking and importance is given for developing the qualities such as attention, will, skill, and patience, and it is emphasized that acquiring conscious impressions and experiences will be possible by means of observation. It is possible for the child to know his/her environment, to express him/herself, to acquire sensitivity, to train his/her senses and to acquire aesthetic experience with the texts prepared according to the child [27]. Moreover in the book, the child had the opportunity of taking the responsibility of self-governing within the learning process.

In conclusion, especially it is thought that the book will be more beneficial for the individuals studying in the field of education or having an occupation related to this field. In this regard, it is recommended that teacher candidates and teachers read this book which we think that it will have a positive contribution to their occupational life.

\section{Note}

A part of this study is presented as verbal announcement in the 2nd International Educational Research Congress. This congress has been achieved in Turkey, Muğla.

\section{REFERENCES}

[1] M. Z. Dirik. Curriculum and Instruction-Principles and Methods of Teaching. Ankara, Pegem Publishing, 2014.

[2] E. Arı. Basic Concepts. F. Büyükalan (Ed.), Teaching and Learning Theories and Approaches in (pp 2-21). Ankara, Pegem Publishing, 2009.

[3] S. Fer. Instructional Design, Ankara, Anı Publishing, 2011.

[4] Z. Çubukçu. Curriculum Design and Development, Bilal Duman (Ed.), Principles and Methods of Teaching in (pp. 65-105), Ankara, An1 Publishing, 2011.

[5] D. H. Schunk. Learning Theories-An Educational Perspective (M. Şahin, Çev.) Ankara, Nobel Publishing, 2011.

[6] L. Küçükahmet. Curriculum Development and Instruction. Ankara, Nobel Publishing, 2009.

[7] N. Senemoğlu. Development, Learning and Teaching. Ankara, Pegem Akademi Publishing, 2009.

[8] Ö. Demirel. Didactics. Ankara, Pegem A Publishing, 2011.

[9] O. Karamustafaoğlu. and S. Yaman, Special Teaching Methods in Science Education, Ankara, An1 Publishing, 2010.

[10] Y. Eser. Curriculum Development, 2010. [Online]. Available:http://edebiyat.karabuk.edu.tr/pformasyon/icerikle r/yeser/PFS109\%20PROGRAM\%20GEL\%C4\%B0\%C5\%9 ET\%C4\%B0RME\%2010.\%20HAFTA.pdf. [Accessed 19 February 2015].

[11] S. Çepni, E. Çil, Science and Technology Program of the Primary and Secondary School Teachers Handbook, Ankara, Pegem Publishing, 2009. 
[12] M. Hesapçığlu, Principles and Methods of Teaching, Ankara, Nobel Publishing, 2008.

[13] M. Ergün, and A. Özdaş. Curriculum and Instruction, 1997. [Online].

Available:http://www.egitim.aku.edu.tr/metod03.htm.

[Accessed 02 March 2015].

[14] Z. Altürk, and M. Ünlü. Analysis of Activity Principle in Geography Textbook, Marmara Geographical Review, Vol. 29, 168-194, 2014.

[15] H. Akyol. Text Analysis in Terms of Structure and Teaching in Textbooks, VII. National Teaching Education Symposium Proceedings, 02-04 May in (pp.712-717). Çanakkale, Onsekiz Mart University, 2008.

[16] P. Çakır. The analysis of stories in 6., 7., 8. classes Turkish coursbooks in terms of "relativism of child", The Master Thesis, Ondokuzmayıs University, Samsun, 2009.

[17] H. Ülper, and K. Yalınkılıç. Qalitative and Quantitive Features of Reading Questions in Turkish Coursebooks Prepared According to The Last Two Turkish Teaching Programme, The Journal of International Social Research, Vol. 12, No. 3, 449-461, 2010.

[18] Ö. Daşcan. Primary Program on Recent Changes, Ankara, Anı Publishing, 2014.

[19] A. Yıldırım, and H. Şimşek. Qualitative Research Methods in The Social Sciences, Ankara, Seçkin Publishing, 2011.
[20] S. Akbayır. What should my child read?, Ankara, Pegem Publishing, 2010.

[21] K. Squire, and H. Jenkins. Harnessing the power of games in education, Insight, Vol. 3, No. 1, 5-33, 2003.

[22] J. Tulloch, and H. Jenkins. Science Fiction Audiences: Watching Doctor Who and Star Trek, London, Routledge, 1995.

[23] D. Court, and E. Rosental. Values embodied in children's literature used in early childhood education in Israeli State schools. Early Childhood Education Journal, Vol. 34, No. 6, 407-414, 2007.

[24] A. S. W. Olsen. Literature circles and ninth grade students: A student-centered approach to reading. Unpublished masters' thesis, Southwest Minnesota State University, Marshall, Minnesota, 2007.

[25] B. Campbell, and F. Lubben. Learning science through contexts: helping pupils make sense of everyday situations, International Journal of Science Education, Vol. 22, No.3, 239-252, 2000

[26] Y. Zorlu. Effects of Activities Based on Modeling Learning Method and Cooperative Learning Model of Students In Elementary Science and Technology Course, Unpublished doctorate' thesis, Ataturk University, Erzurum, Turkey, 2016.

[27] İ. San. Arts Education Theories, Ankara, Ütopya Publishing, 2010. 